\title{
CARCINOID SYNDROME ASSOCIATED WITH
}

\section{PSYCHOSIS}

\author{
Shoukry Mina HanNa, M.B., D.M., D.T.C.D., (Alexandria) \\ Severalls Hospital, Colchester*
}

CARCINOID tumours arise from specialised epithelial cells (Kuschitsky cells) of the gastro-intestinal tract. These cells can secrete 5-hydroxytryptamine (5-HT, serotonin), an excessive quantity of which, in patients suffering from metastasizing carcinoids, produces a syndrome characterised by atypical cyanosis, flushes, diarrhoea, asthma-like attacks and valvular disease of the right side of the heart (Biörck, Axen and Thorson, 1952 and Thorson, Biörck, Bjorkman and Waldenstorm, 1954). The only case of carcinoid syndrome with mental changes found in the literature was that of Hossain (1962): the patient was slow to speak and answer questions, his face dull and expressionless. He showed limited movements and activity, but there was no manifest psychosis. The present case is the first recorded of carcinoid syndrome associated with manifest psychosis; she was treated as a psychiatric patient for more than ten years, and admitted twice to our hospital. Unfortunately the diagnosis was only made at necropsy.

\section{Case Report}

The psychiatric illness started in 1948, when the patient was fifty-five years old, when she became paranoid and suspected the neighbours of stealing her chickens' eggs. Then she began to suffer from bad tempers, became restless at night, had nightmares, and in 1950 had bouts of severe depression and weeping. In 1951 she became so obsessed with persecutory ideas that she became violent and threw bricks at the neighbours' windows. Depression and excitement alternated. She had been seeing her own doctor since 1949; he prescribed different sedatives, which she often did not take, and at the end of 1953 she ceased going to him. In 1954 she began to drink spirits heavily, and she neglected herself and the house. More than once, in periods of violence, she took a knife and threatened to harm herself, but neither her son nor her husband took her threats seriously. By 1955 she had lost interest and was unresponsive, except when she flew into rages for no apparent cause. By 1956 her mental condition had deteriorated further, she was now confused and her memory was impaired. In February, 1957 she went to a public house in the evening, smashed a window and then was admitted for the first time to Severalls Hospital as a certified patient.

On admission she was confused, disorientated, agitated, talkative and paranoid; she did not know her age, denied being married and accused her neighbours of conspiring against her. At times, she became

\footnotetext{
*Present Address: M.R.C. Unit, Hollymoor Hospital,
} Birmingham 31. extremely excited and used bad language. There was no previous family history of mental illness.

Examination revealed no abnormalities, apart from B.P. $160 / 100 \mathrm{~mm}$. Hg. with a short systolic murmq1 over the apex. Hb. $58 \%$ ESR $39 \mathrm{~mm}$. $/ \mathrm{hr}$. $8 \mathrm{~A}$ diagnosis of a confusional state was made. Duriag her stay in the hospital she remained confused and disorientated and was treated with paraldehyde oralfy during the day and sodium amytal at night.

After two months in the hospital without mu change in her symptoms her husband discharged hier against advice. At home her condition remained tge same. She neglected herself, her condition deterioratgd and she had to be certified and readmitted to hospital again in November, 1962.

On the second admission she was very confusga and disorientated. She was well-built; no dyspnoea or cyanosis; sinus tachycardia, rate $100 / \mathrm{min}$. B.झ. $150 / 90$. Examination of the other systems didonot reveal any abnormalities apart from sacral oeden and pitting oedema of the lower limbs which onad been present for nearly a month before admisiocio.

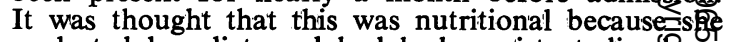
neglected her diet, and had had persistent diarroea for some time before admission. Plasma proteigs 5.8 g. $/ 100 \mathrm{ml}$., albumin $2.1 \mathrm{~g}$., globulin $3.7 \mathrm{~g}$. Whife in hospital she had repeated attacks of diarrhoeg. Examination of the stools did not reveal any path8gens. She developed a macular rash over her bods mainly the upper limbs. Her condition deteriorated gradually and she died a fortnight after admission.

Necropsy: (Dr. Anderson). The small intestipe shows nodules of tumour tissue, for the most part submucosal, composed of solid clusters of sma 1 uniform ovoid cells which occasionally tend assume a glandular pattern. In both instances tumour cells can be traced to the mucosa, whist more deeply the muscularis is infiltrated, but not breached. Liver - there is a large discrete metasta: tumour composed of ovoid or spindle shaped ceflis arranged in solid communicating clusters. TRe surrounding liver tissue shows pronounced faty degeneration. Comment-these three neoplasms are all typical carcinoid tumours.

\section{Discussion}

Serotonin (5-HT) inhibits the transmission of some nerve impluses, including their passage from one side of the brain to the other through the corpus callosum, and of pain impulses from various parts of the body.

The first evidence of the participation of serotonin in mental disease was provided 1954 by Woolley and Shaw: a number of drug which caused, in normal men, some of the signs of schizophrenia were structural analogues 
serotonin and acted as antimetabolites. The subsequent discovery of a variety of psychosisinducing chemical agents, each of which was clearly linked to serotonin, has added support to this hypothesis. Some of these agents have been found in plant sources and others have been synthesized. Excitement may be caused by drugs having a serotonin-like action: normal men have been made to develop a transient condition resembling schizophrenia and the increase in serotonin content of the brains of a few schizophrenic subjects induced by administration of the serotonin precursor, 5-hydroxytryptophan, has resulted in a worsening of their condition. (Woolley, 1958). Such findings are compatible with the hypothesis that an excess of serotonin in the brain lends to hallucinations and schizophrenic manifestations.

That depression can result from a deficiency of serotonin in the brain is supported by much clinical work which has been done with drugs which inhibit mono-amine oxidase, the enzyme chiefly responsible for destroying serotonin. These inhibitors increase brain serotonin and relieve simple depressions, and have usually been found to worsen the condition of schizophrenia.

-When serotonin is injected it is rapidly destroyed by specific enzymes and no increase in its concentration in the brain can be demonstrated unless a mono-amine oxidase inhibitor is given simultaneously (Costa and Aprison, 1958). The location of serotonin-destroying enzymes in the walls of cerebral capillaries may therefore act as a blood-brain barrier (Woolley, 1958). Presumably this is why patients with the carcinoid syndrome do not develop mental changes. This barrier was possibly defective in this patient, and the carcinoid tumour was responsible for the psychosis. The fact that she started drinking heavily as a result of the psychosis, and that apart from fatty degeneration of the liver there were no other manifestations of chronic alcoholism, is evidence against the latter as a cause.

There were no signs of a deficiency of nicotinic acid which sometimes accounts for mental changes. There were no major cerebral arteriosclerotic changes. In a manic-depressive state, intelligence and memory are usually unimpaired; only when manic excitement is severe are clouding of consciousness and confusion observed. Generally speaking, depression and mania occur in a setting of clear consciousness. This serves to differentiate affective disorders from similar psychoses. (Mayer-Gross, 1960).

\section{Summary}

A case of carcinoid tumour is reported that presented with psychosis fourteen years before diagnosis at necropsy. This is the first case to be recorded with such an association.

\section{REFERENCES}

Biorck, G., Axen, O., and ThORson, A. (1952): Unusual Cyanosis in a Boy with Congenital Pulmonary Stenosis and Tricuspid Valve Insufficiency, Fatal Outcome, Amer. Heart J., 44, 143.

COSTA, E., and APRISON, M. H. (1958): Distribution of Intracarotidly Injected Serotonin in the Brain, Amer. J. Physiol., 192, 95.

Hossain, M. A. (1962): Carcinoid Syndrome with Unusual Features, Postgrad. med. J., 38, 204.

MAYer-Gross (1960): Clinical Psychiatry, 2nd Edition, London: Cassell.

THORSON, A., BIORCK, A., BJORKMAN, G., and WALDENSTROM, J. (1954): Malignant Carcinoid of the Small Intestine with Metastases to the Liver, Valvular Disease of the Right Side of the Heart, Peripheral Vasomotor Symptoms, Broncho Constriction, and an Unusual Type of Cyanosis: A Clinical and Pathological Syndrome, Amer. Heart J., 47, 795.

WoOlley, D. W., and SHAW, E. (1954): Some Neurophysiological Aspects of Serotonin, Brit. med. J., ii, 122.

Woolley, D. W. (1958): Serotonin in Mental Disorders, Ass. Res. nerv. Dis. Proc. Res. Pub., 36, 381.

\title{
AKENETIC MUTISM FOLLOWING COAL-GAS POISONING
}

\section{WITH SUBSEQUENT RECOVERY}

\author{
T. F. Mackintosh \\ Poisons Treatment Centre, The Royal Infirmary, Edinburgh, 3.
}

THERE ARE many sequelae to carbon monoxide poisoning and one of the most unusual is the development of akinetic mutism; the patient to be described developed this state after a suicidal attempt by gassing. She eventually recovered spontaneous speech and movement and only then did she show evidence of an upper motor neurone lesion.
Akinetic mutism is rarely encountered in general medical practice and most patients in whom this state occurs are suffering from severe disease from which recovery does not take place. However, occasionally it can occur in a patient whose illness is in itself not fatal; the patient to be described falls into this category. Recovery from akinetic mutism has rarely been reported and 